\title{
Politics of Water Use and Its Effects on Water Research of Horticultural Crops: Introduction to the Colloquium
}

\author{
Alexander A. Csizinszky \\ Gulf Coast Research and Education Center, University of Florida, Institute of Food and Agricultural Sciences, \\ 5007 60th Street East. Bradenton. FL 34203
}

Water is one of the most important components in biological systems, as biological functions depend completely on water. In green plants, water is an essential structural component of protoplasm and membranes, supplier of $\mathrm{H}^{+}$, nutrient solvent, and participant in photosynthesis (Salisbury and Ross, 1985). In higher plants, to which the majority of horticultural crops belong, water is essential for mineral transport and food translocation, transpiration to stabilize plant temperature, and respiration. Seed germination and plant growth, composition, and enzymatic and hormonal functions also depend on water (Crafts, 1968; Gates, 1968; Kirkham, 1990). In the basic step of photosynthesis, for each $\mathrm{CO}_{2}$ molecule reduced, two $\mathrm{H}_{2} \mathrm{O}$ molecules are oxidized. Thus, each glucose molecule produced by the plant requires $12 \mathrm{H}_{2} \mathrm{O}$ molecules. In controlled experiments with vegetable and ornamental crops, photosynthetic rates were greatly reduced and, consequently, plant growth and development retarded when water supply was restricted (Behboudian, 1977; Gates, 1968; Wright and Stark, 1990). The largest amount of water is used for transpiration (Hanks, 1982). Corn, for example, transpires $225 \mathrm{~kg}$ of water for each $1 \mathrm{~kg}$ of dry matter (shoots, roots, cobs, and seeds) produced (Hanks, 1983). Without irrigation, horticultural crops in major U.S. production areas, especially in western states, could not be produced economi-

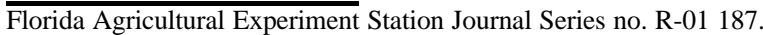

tally, if at all. Water resources, which were considered almost inexhaustible in past decades, are under severe stress, because water is being pumped from its source at a higher rate than it is being recharged. For example, in the Ogallala aquifer on the southern Texas high plains, the area irrigated declined by $27 \%$ and the annual water withdrawals for agriculture declined by 40\% from 1974 to 1984 (Lee and Lacewell, 1990). Reduced well yields and increased pumping costs have made irrigation too expensive for some major crops in that area.

With increased population growth, especially in urban areas, and increased industrial and commercial activities, less water is or will be available for agricultural use. Municipal water suppliers, industry, and agriculture increasingly compete for water-a renewable but finite resource in several U.S. areas (Robbins, 1990; Waterfield, 1989). Water quantity and its distribution among the user groups thus has become a sociopolitical issue that will continue to affect agriculture. Ultimately, water will be controlled by elected legislatures, which, in turn, will create agencies to carry out policies (Leopold, 1990; Anonymous, 1990). In southwestern Florida, a water management agency recommended that, by 2000 , agricultural operations must increase their irrigation system efficiencies from the current $40 \%$ to $85 \%$ (Graddy, 1990). At the same time, per capita water consumption must decrease from the current 700 liters/day per person (lpd) to $454 \mathrm{lpd}$. There are also indications that water-poor counties and municipalities 
within a state, or water-poor states with growing populations, want to tap the resources of their water-rich neighbors (Hauserman, 1990; Robbins, 1990). Dwindling available water resources create problems not only for the general public and governmental regulatory agencies, but also for scientists working on water research and crop production. The agricultural industry expects scientists to conduct research and find methods to produce crops with less water and without reducing yield quantity and quality.

In this colloquium, participants from the U.S. Geological Survey, the Environmental Defense Fund, and the U.S. House of Representatives (no written material submitted) presented their views on the problems associated with water use and distribution in the United States. Researchers presented results on the effects of reduced water use in producing ornamentals, turfgrass, fruit, and vegetables.

\section{Literature Cited}

Anonymous. 1990. Water-use bills before Michigan legislature. Great Lakes Veg. Growers News Jan. 1990:63.

Behboudian, M.H. 1977. Water relations of cucumber, tomato, and sweet pepper. Dept. of Horticulture, Agricultural Univ., Wageningen, The Netherlands. Publ. 439.

Crafts, AS. 1968. Water deficits and physiological processes, p. 85-133. In: T.T. Kozlowski (ed.). Water deficits and plant growth. vol. 2. Academic, New York.

Gates, C.T. 1968. Water deficits and growth of herbaceous plants. In: T.T.
Kozlowski (ed.). Water deficits and plant growth. vol. 2. Academic, New York.

Graddy, J. 1990. Water. Citrus \& Veg. Mag. 53(9):64-67.

Hanks, R.D. (ed.). 1982. Predicting crop production as related to drought stress under irrigation. Utah Agr. Expt. Sta. Res. Rpt. 65:367.

Hanks, R.D. 1983. Yield and water use relationships: An overview, p. 393-411. In: H.M. Taylor. (ed.). Limitations to efficient water use in crop production. Amer. Soc. Agron., Crop Sci. Soc. Amer., Soil Sci. Soc. Amer., Madison, Wis.

Hauserman, J. 1990. Water wars. Tallahassee Democrat 85(266)5F:8.

Kirkham, M.B. 1990. Plant responses to water deficits, p. 323-342. In: B.A. Stuart and D.R. Nielsen (eds.). Irrigation of agricultural crops. Amer. Soc. Agron., Crop Sci. Soc. Amer., Soil Sci. Soc. Amer., Madison, Wis. Agron. Monogr. 30

Lee, J.G. and R.D. Lacewell. 1990. Farm program impacts on an exhaustible groundwater supply: An analysis of the Texas southern high plains. Water Resources Res. 26:361-368.

Leopold, L.B. 1990. Ethos, equity and the water resource. Environment 32: 1742.

Robbins, J. 1940. A drinking problem. Boston Globe 237(155):10.

Salisbury, F.B. and C.W. Ross. 1985. Plant physiology. Wadsworth Publishing Co., Belmont, Calif.

Waterfield, L. 1989. Water fight could result in arid Eden. Packer 66(45):4.

Wright, J.L. and J.C. Stark. 1990. Potato, p. 859-888. In: B.A. Stuart and D.R. Nielsen (eds.). Irrigation of agricultural crops. Amer. Soc. Agron., Crop Sci. Soc. Amer., Soil Sci. Soc. Amer., Madison, Wis. Agron. Monogr. 30. 